\title{
FUNGSI KOMUNIKASI ANTAR PRIBADI ANTARA KONSELOR DENGAN DAMPINGAN PADA UPAYA PENANGANAN KORBAN PENELANTARAN RUMAH TANGGA (Studi Kasus di Lembaga Sosial Masyarakat (Lsm) SAPUAN (Sahabat Perempuan Dan Anak) Blitar)
}

\author{
Andiwi Meifilina \\ Program Studi Ilmu Komunikasi Fakultas Ilmu Sosial dan Ilmu Politik \\ Universitas Islam Balitar Blitar \\ Email: andiwimeifilina@unisbablitar.ac.id
}

\begin{abstract}
The problem that is encountered is there are still victims who have difficulty in terms of communication with the counselor. This is indicated by the number of assistants who are still afraid, passive, emotional and crying in complaining. Seeing this problem, interpersonal communication is very important to be owned by the victims because the beneficiaries are expected to communicate well in solving and to convey the problem to the counselor. The type of approach chosen in this research is descriptive qualitative study about interpersonal communication function between counselor and household neglect victim at LSM (Non-Governmental Organization) of SAPUAN (Friends of Woman and Children) Blitar.
\end{abstract}

Research on the interpersonal communication function between counselor and assistant to the effort of handling victim neglect of household in nongovernmental organization LSM (Friends of girl and child) Blitar using qualitative descriptive method. With this type of case study approach.

And the interpersonal communication function between the counselor and the victim on the effort of handling the neglected victim of the household in LSM is very important because it involves the relationship between the victim with the counselor and the interpersonal communication relationship must go well so that there is no gap or distance between counselor and victim. And the interpersonal communication function that exist in non-governmental organizations LSM SAPUAN (Friends of women and children), namely: Interpersonal communication helps the development of intellectual and social, Identity or our identity formed in and through communication with others, In order to understand the reality around us and testing the truths of the impressions we have about the world around us, we need to compare with the impressions and perceptions we have about the world around us, we need to compare them with the impressions and understandings of others and the reality Similarly, our mental health is largely determined by the quality of our communication or relationships with others, especially those who are significant figures in our lives.

Keywords: Interpersonal communication, counselor, victim, neglect of household, LSM SAPUAN (Mother and child friend) 


\section{PENDAHULUAN}

Komunikasi sebagai sebuah proses pertukaran simbol verbal dan nonverbal antara pengirim dan penerima untuk merubah tingkah laku, kini meliputi proses yang lebih luas. Komunikasi bukan hanya sebagai alat penyampaian informasi kepada orang lain, tetapi juga sebagai sarana bagi pengkoordinasian dari segala aktivitas yang berlangsung dalam suatu perusahaan. Komunikasi yang tepat bukan hanya komunikasi yang melibatkan komunikator dengan komunikan sebagai pemberi dan penerima pesan, namun juga bagaimana seorang komunikator dapat menyampaikan pesan yang dimengerti oleh komunikan serta bagaimana seorang komunikan mampu menafsirkan pesan yang telah disampaikan komunikator .

Dalam lembaga sosial masyarakat (LSM) SAPUAN (Sahabat ibu dan anak) selalu berusaha memberikan pelayanan terutama dalam berkomunikasi dengan dampingan. Pentingnya dari sebuah komunikasi membuat setiap lembaga sosial masyarakat (LSM) SAPUAN (Sahabat ibu dan anak) agar dapat menyediakan pelayanan yang baik dengan menutupi jurang yang terbentang antara pihak lembaga sosial masyarakat (LSM) dengan masyarakat sebagai publiknya untuk membuat hubungan yang lebih baik. Oleh karena itu suatu lembaga sosial masyarakat (LSM) SAPUAN (Sahabat ibu dan anak) harus mampu tampil professional dan dapat melayani keluhan dari masyarakat. Maka jelas bahwa kebutuhan konselor yang merupakan bagian dari divisi advokasi pada lembaga swadaya masyarakat (LSM), sangatlah mutlak diperlukan. Karena seorang konselor berperan sebagai media komunikator antara dampingan dengan pihak lembaga swadaya masyarakat (LSM) yang meliputi keluhan, keinginan dan kebutuhan akan informasi dari dampingan tersebut. 
Permasalahan yang ditemui adalah masih ada dampingan yang mengalami kesulitan dalam hal komunikasi dengan konselor. Hal ini ditunjukkan banyaknya dampingan yang masih takut, pasif, emosi dan menangis dalam menyampaiakan keluhannya. Melihat permasalahan ini maka komunikasi antar pribadi sangatlah penting untuk dimiliki oleh para dampingan karena dampingan diharapkan dapat berkomunikasi dengan baik dalam menyelesaikan dan untuk menyampaikan permasalahannya kepada konselor.

\section{METODE PENELITIAN}

Studi kasus deskriptif kualitatif merupakan jenis pendekatan yang dipilih dalam penelitian ini. Penilitian ini bertujuan untuk membuat deskriptif secara sistematif, faktual dan akurat tentang fakta-fakta atau sifat-sifat objek tertentu (Kriyantono, 2006 : 69). Lebih jelasnya penelitian ini tentang fungsi komunikasi antar pribadi antara konselor dengan para korban penelantaran rumah tangga di Lembaga Swadaya Masyarakat (LSM) SAPUAN (Sahabat Perempuan dan Anak) Blitar.

Penelitian tentang fungsi komunikasi antar pribadi antara konselor dengan dampingan pada upaya penanganan korban penelantaran rumah tangga di lembaga swadaya masyarakat (LSM) SAPUAN (Sahabat perempuan dan anak) Blitar mengunakan metode deskripif kualitatif. Dalam tidak menguji hipotesis atau membuat prediksi namun penelitian ini memaparkan situasi dan langkah-langkahnya adalah mendiskripsikan masalah, menentukan bagaimana prosedur penelitian, mengumpulkan data dan mengolah hasilnya serta menganalisis hasil data yang sudah diolah lebih lanjut.

\section{PEMBAHASAN}

Bentuk utama komunikasi antarpribadi yaitu komunikasi tatap muka dimana komunikasi ini merupakan suatu rangkaian pertukaran pesan dua individu pada 
proses komunikasi. Dua individu yang melakukan komunikasi tersebut saling bertukar pesan bergantian. Keberadaan interaksi antar individu inilah yang memperlihatkan komunikasi antar pribadi menghasilkan suatu umpan balik pada tingkat tertentu. Jarak fisik partisipan yang dekat sekali membuat aksi dan reaksi secara langsung terlihat. Interaksi dari komunikasi antar pribadi mampu menghasilkan suatu perubahan sikap, pendapat, perilaku bahkan suatu tindakan.

Komunikasi antar pribadi sebenarnya adalah proses sosial dimana individu yang terlibat di dalam komunikasi tersebut saling mempengaruhi. Sebagaimana yang dijelaskan oleh Devito dalam Liliweri (1991:13) komunikasi antar pribadi dapat diartikan sebagai pengiriman pesan dari seseorang yang diterima orang lain maupun sekelompok orang dengan efek dan umpan baliknya bersifat langsung.

Cassagrande dalam Liliweri (1991:13) memiliki pendapat jika seseorang melakukan komunikasi dengan orang lain karena:

1. Setiap orang terlibat dalam proses perubahan yang cukup cepat.

2. Setiap orang perlu orang lain untuk saling membagi kelebihan dan mengisi kekurangan.

3. Interaksi hari ini adalah spektrum pengalaman dari masa lalu dan juga menjadikan orang mengantisipasi bagaimana masa depan nantinya.

4. Hubungan yang telah diciptakan jika berhasil akan menjadi pengalaman baru.

Komunikasi antar pribadi dapat juga meningkatkan hubungan kemanusiaan antara pihak-pihak yang berkomunikasi. Berlandaskan pendapat Casagrade dapat disimpulkan keinginan berkomunikasi secara pribadi disebabkan adanya dorongan pemenuhan kebutuhan yang belum dan tidak dimiliki seseorang sebelumnya. Menurut Cangara (2004:33), dengan bekerja lebih untuk meningkatkan hubungan 
insani maka akan dapat menghindari dan juga mengatasi beberapa konflik pribadi, mengurangi ketidakpastian serta berbagi pengalaman dan pengetahuan bersama yang lain. Itu semua merupakan fungsi dan tujuan komunikasi antar pribadi.

\section{A. Fungsi komunikasi antar pribadi}

Pada upaya penanganan korban penelantaran rumah tangga yang terdapat di lembaga swadaya masyarakat (LSM) SAPUAN (Sahabat perempuan dan anak) Blitar pada fungsi komunikasi antar pribadi antara konselor dengan dampingan, melibatkan hubungan antara dampingan dengan konselor yang ada di lembaga swadaya masyarakat (LSM) SAPUAN (Sahabat perempuan dan anak) yaitu:

1. Komunikasi antar pribadi membantu perkembangan intelektual dan sosial. Bahwa dalam perkembangan intelektual dan sosial kita sangat di tentukan oleh kualitas komunikasi kita dengan orang lain. Sehingga dengan adanya LSM SAPUAN akan membantu menambah wawasan dan pengetahuan intelektual dan sosial kepada masyarakat dan masyarakat akan merasa lebih mudah dan berani dalam menghapi persoalan atau masalahnya.

Adapun masalah yang dihadapi perempuan adalah penelantaran rumah tangga Kebanyakan ibu-ibu rumah tangga takut dan kurang mengerti apa yang dialaminya. Kebanyakan ibu rumah tangga melihat penelantaran rumah tangga karena faktor ekonomi padahal ada juga yang suami memang tidak mau menafkahi keluarga sehingga ibu -ibu tidak pernah melaporkan penelantaran rumah tangga yang dialami.

Selain itu sedikitnya pengetahuan ibu-ibu rumah tangga tentang penelantaran rumah tangga sehingga para korban penelantaran rumah tangga takut untuk mengadukan kepada pihak yang berwajib. Dengan adanya fungsi komunikasi 
antar pribadi LSM SAPUAN akan menambah pengetahuan dan wawasan para korban penelantaran rumah tangga tersebut.

2. Melalui komunikasi dua arah, identitas maupun jati diri manusia akan dapat terbentuk. Selama berkomunikasi dengan orang lain, secara sadar maupun tidak sadar kita mengamati, memperhatikan dan mencatat dalam hati semua tanggapan yang diberikan oleh orang lain itu tentang diri kita. Berkat pertolongan komunikasi dengan orang lain kita dapat menemukan diri yaitu mengetahui siapa diri kita sebenarnya.

Jati diri atau identitas yang terbentuk melalui proses komunikasi dua arah merupakan fungsi komunikasi antar pribadi LSM SAPUAN. Dengan adanya peran komunikasi antar pribadi konselor dapat mengerti apa yang dibutuhkan oleh dampingan karena konselor mampu melihat identitas atau jati diri dampingannya. Seperti kasus mengahadapi penelantaran rumah tangga dengan ibu rumah tangga yang memiliki pendidikan rendah. Korban penelantaran rumah tangga tersebut pasti mengalami kesulitan dalam menceritakan peristiwa yang dialaminya, keterbatasan bahasa dalam proses berkomunikasi.

3. Perlunya mempertimbangkan kesan-kesan dan pengertian tentang dunia di sekitar. Selain itu, perlu juga membandingkannya dengan kesan-kesan dan pengertian orang lain dan realitas yang sama untuk memahami realitas di sekeliling serta menguji kebenaran kesan-kesan dan pengertian yang dimiliki tentang dunia sekitar. Tentunya perbandingan sosial seperti itu hanya mampu dilakukan melalui komunikasi dua arah.

Dan fungsi komunikasi antar pribadi lembaga swadaya masyarakat (LSM) SAPUAN (Sahabat perempuan dan anak) akan selalu menyamakan 
persamaan persepsi dan realitas anatara konselor dengan dampingan . Contoh bahwa suatu peristiwa penelantaran rumah tangga pasti memiliki persepsi yang berbeda antara konselor dengan dampingan.

4. Kualitas komunikasi atau hubungan kita dengan orang lain, terlebih orangorang yang merupakan tokoh-tokoh signifikan dalam hidup kita menentukan sebagian besar kesehatan mental kita. Bila hubungan kita dengan orang lain diliputi berbagai masalah, maka tentu kita akan menderita, merasa sedih, maka rasa sepi dan terasing yang mungkin kita alamipun tentu akan menimbulkan penderitaan, bukan hanya penderitaan emosional atau batin, bahkan bias juga penderitaan fisik.

Fungsi komunikasi antar pribadi lembaga LSM SAPUAN dalam kesehatan mental sangat penting karena konselor pasti mengahadapi masyarakat yang penuh masalah sehingga konselor harus bisa menjaga komunikasi antar pribadi ini dengan baik. Salah satu contoh adalah sikap ramah dan sabar kepada dampingan sehingga dampingan akan mudah untuk didekati oleh konselor dalam menghapi masalahnya baik masalah penelantaran rumah tangga

\section{B. Teori Komunikasi Emosional oleh Allen Dittman (Liliweri, 1997: 85)}

Allen Dittman telah menggunakan suatu teori penting mengenai komunikasi emosi. Dia membagi paradigma ini ke dalam tiga jenis perilaku: 1) informasi perasaan 2) tanda/ isyarat perasaan dan 3) saluran untuk menyatakan perssaan.

1. Informasi perasaan, menurut Dittman emosi adalah bentuk dan suasana kebatinan individu yang dinyatakan dalam perilaku yang menyimpang dari perilaku biasa ditampilkan. Dampingan dalam menyampaikan permasalahannya kepada konselor akan bersikap emosi dengan menangis dan berteriak. 
2. Isyarat/ Tanda Perasaan yaitu menyatakan perasaan atau emosi kepada orang lain dengan isyarat-isyarat tertentu. Dampingan dalam menyampaikan permasalahannya kepada konselor terkadang menggunakan isyarat dengan menggelengkan kepala atau menganggukkan kepala kalau dampingan merasa takut untuk menyampaikan permasalahannya.

3. Saluran Komunikasi Perasaan, menurut Dittman ada tiga saluran yang digunakan untuk menyatukan perasaan yaitu:

a. Audible, merupakan saluran pernyataan emosi melalui bahasa dan pralinguistik. Dampingan berkomunikasi antar pribadi dalam menyampaikan permasalahnnya dengan konselor kadang sangat emosi dengan menggunakan bahasa-bahasa yang kasar tentunya.

b. Visual, merupakan saluran pernyataan emosi melalui tampilan raut wajah dan gerakan anggota tubuh. Dampingan berkomunikasi antar pribadi dalam menyampaikan permasalahnnya dengan konselor biasanya raut wajah memerah dan tegang.

c. Psyco-psysiological, merupakan saluran pernyataan emosi berupa tanda yang memancar dari fungsi gerakan-gerakan tubuh. Dampingan berkomunikasi antar pribadi dalam menyampaikan permasalahnnya dengan konselor terkadang suaranya terengah-engah dan meremas tangannya.

\section{PENUTUP}

Bahwa fungsi komunikasi antar pribadi antara konselor dengan dampingan pada upaya penanganan korban penelantaran rumah tangga di lembaga swadaya masyarakat (LSM) SAPUAN (Sahabat perempuan dan anak) Blitar sangat penting 
karena melibatkan hubungan antara dampingan dengan konselor dan hubungan komunikasi antar pribadi harus berjalan dengan baik agar tidak terjadi jurang pemisah atau jarak antara konselor dengan dampingan. Hal yang sangat mendukung dari komunikasi antar pribadi adalah keterbukaan dan empati. Keterbukaan antara dampingan (korban) dengan konselor di lembaga swadaya masyarakat (LSM) SAPUAN (Sahabat perempuan dan anak) Blitar sangat perlu karena dengan adanya keterbukaan dari dampingan maka konselor dapat memberikan solusi yang tepat untuk permasalahan dampingan dalam hal penelantaran rumah tangga. Sedangkan empati ini akan mewujudkaan rasa persaudaraan atau kekeluargaan antara dampingan dan konselor dimana konselor juga dapat merasakan apa yang dirasakan oleh dampingan.

\section{DAFTAR PUSTAKA}

Arifin, A., 1984. Strategi Komunikasi: Sebuah Pengantar Ringkas. Bandung: Armico.

Cangara, H. ,2013. Perencanaan dan Strategi Komunikasi. Jakarta: Rajawali Pers. , 2014. Edisi kedua. Pengantar Ilmu Komunikasi. Jakarta: Rajawali Pers.

Effendy, O. U, 2013. Ilmu Komunikasi Teori dan Praktek. Bandung: PT Remaja Rosdakarya. , 2008. Dinamika Komunikasi. Bandung: PT Remaja Rosdakarya.

Hamidi, 2004. Metode Penelitian Kualitatif, UMM Press, Malang

Kriyantono, Rachmat, 2006. Teknik Praktis Riset Komunikasi, Jakarta, Kencana

Liliweri, Alo, 1997. Komunikasi Antarpribadi, PT. Citra Aditya Bakti, Bandung 
Mulyana, Deddy, 2007. Ilmu Komunikasi Suatu Pengantar, Bandung, Remaja Rosdakarya

Rakhmat, Jalaluddin, 2005. Psikologi Komunikasi, Bandung, Remaja Rosdakarya , 2009. Metode Penelitian Komunikasi, Bandung, Remaja

Rosdakarya

Sendjaja, Sasa Djuarsa, 2003. Pengantar Ilmu Komunikasi, Pusat Penerbitan Universitas Terbuka, Jakarta

Sugiyono. 2010. Metode Penelitian Kuantitatif, Kualitatif, dan Kombinasi (Mixed Methods). Bandung: Alfabeta.

Vardiansyah, Dani, 2004. Pengantar Ilmu Komunikasi, Ghalia Indonesia, Jakarta Widjaja, H.A.W,2000. Ilmu Komunikasi Pengantar Studi, Rineka Cipta, Jakarta 